\title{
Sonoma County Organization of Public Employees v. County of Sonoma: The Contract Clause and Home Rule Powers Revitalized in California
}

In Sonoma County Organization of Public Employees v. County of Sonoma, ${ }^{1}$ the California Supreme Court overturned state legislation placing a ceiling on wage increases for employees of local entities accepting grants of state funds. Although the legislation was only of short-term duration, the court held that, in the absence of a compelling emergency, such an impairment of contract rights violates the contract clauses of the federal and state constitutions. ${ }^{2}$ The court further held that the state's attempt to restrict salaries of local public employees, even in the guise of a condition, was contrary to the state constitution's home rule provision granting absolute power to chartered cities to set local employees' wage scales. ${ }^{3}$

Part I of this Note briefly describes the political events behind the decision in Sonoma. Part II analyzes the court's treatment of the impairment of contract issue, and argues that, while the court reached a correct result, it did so by creating an emergency threshold requirement which is unjustified by precedent and too broad and uncertaim in scope. Part III considers the home rule issue and argues that the court's home rule analysis is inaccurate and unresponsive to the real problems raised by the legislation. The section then describes an alternative means of assessing the constitutionality of the legislation, viewing it not as an intrusion imto municipal affairs but rather as a condition on a grant of state monies.

I.

The Decision

On June 6,1978, Califorma voters approved a ballot initiative known as Proposition 13, which constitutionally limited the taxes that local and state agencies could impose on real property located within

1. 23 Cal. 3d 296, 591 P.2d 1, 152 Cal. Rptr. 903 (1979) (Mosk, J.) (unanimous decision).

2. U.S. Const. art. I, $\S 10$, cl. 1; CAL. Const. art. I, $\S 9$.

3. CAL. Const. art. XI, § 5(b). 
the state. ${ }^{4}$ Because the limitation dramatically reduced the revenues of local government entities, they faced the possibility of laying off employees and cutting back essential services. While the state legislature "bailed-out" those local entities with surplus state funds, ${ }^{5}$ it also added sections $16280^{6}$ and $16280.5^{7}$ to the Government Code, tying receipt of "bail-out" funds to limits on 1978-1979 wage increases for local employees. The legislation also purported to void any provisions of a contract, agreement, or memorandum of understanding between local entities and their employees granting a wage increase, to the extent that the increase exceeded those granted to state employees. ${ }^{8}$ Five unions representing local public employees denied pay increases by the legislation filed original petitions with the California Supreme Court for writs of mandate to compel the respondent local entities ${ }^{9}$ to adhere to the agreements. The petitions raised two issues: whether the legislature's invalidation of the wage increase provisions was an impairment of contract in violation of the state and federal constitutions, and whether sections 16280 and 16280.5 violated the home rule provisions of the California Constitution. The court granted the writs mandating that the state provide the "bail-out" monies to the local entities without the restrictions. Simce all the cases before the court involved employment contracts providing for cost-of-living increases, the writ might have issued solely on the basis of a finding of impairnient of contract. Instead, the court rendered a broader decision based on the home rule rights

4. See CAL. CONST. art. XIIIA. The constitutionality of this amendment was upheld in Amador Valley Joint Union High School Dist. v. State Bd. of Equalization, 22 Cal. 3d 208, 583 P.2d 1281, 149 Cal. Rptr. 239 (1978).

5. CAL. Gov't CoDE $\S \S 16250-16285$ (West Supp. 1979).

6. California's Government Code $\$ 16280$ reads in part:

No state funds from the state surplus or state loan funds shall be available to any local public agency which provides a cost-of-living wage or salary incrcase in the 1978 . 79 fiscal year for local public agency employees... . if such increase is in excess of the cost-of-living salary increase provided for state einployees. . . .

Any provision of a contract, agreement, or memorandum of understanding between a local public agency and an employee organization or an individual employee which provides for a cost-of-living wage or salary increase to local public agency employees in excess of sucl increase provided for state employees is null and void to the extent of such excess.

CAL. Gov't CODE $\S 16280$ (West Supp. 1979).

7. California's Government Code $\S 16280.5$ reads in part as follows:

No state funds from the state surplus or state loan funds shall be available to any local public agency which provides an mcrease in salary in the 1978-79 fiscal year to any elected or appoimted noncivil service officer of the local public agency.

Any provision of a contract or agreement between a loeal public agency and an elected or appointed noncivil service officer of the local pubhic agency which provides for an increase im salary is null and void.

Cal. Gov't Code $§ 16280.5$ (West Supp. 1979).

8. Cal. Gov'T Code $\S 16280$ (West Supp. 1979).

9. The respondents, four counties, the City of Long Beach, and some of their legislative bodies and officers, are referred to as "counties" in this Note. 
contained in the California Constitution and invalidated the legislation as applied to all local employees, with or without contracts. ${ }^{10}$

II.

\section{FINDING AN IMPAIRMENT}

To assess the legality of Section 16280 in light of federal and state constitutional prohibitions on laws impairing contract obligations, ${ }^{11}$ the court first determined that the employment agreements at issue were "contracts"12 within the scope of the respective contract clauses. The court then concluded that the legislation did impair these contracts ${ }^{13}$ simce Section 16280 expressly declared null and void any provision of a contract, agreement, or memorandum of understanding which permitted a wage increase to the extent the increase exceeded that given state employees. ${ }^{14}$

A finding of impairment does not automatically invalidate legislation, however. ${ }^{15}$ Despite the absolute terms in which the federal contract clause is cast, ${ }^{16}$ courts have interpreted the clause to permit impairment under certain circumstances. The task of courts confronted with an impairment claim is to determine whetler the circumstances prompting passage of the challenged legislation justify the impairinent.

The United States Supreme Court developed this principle at length in Home Building and Loan Association v. Blaisdell. ${ }^{17}$ The Blaisdell decision upheld a Minnesota statute enacted during the Depression to protect homeowners by declaring a moratorium on niortgage foreclosures, even though this statute directly conflicted with the lender's contractual foreclosure rights. According to the Sonoma court,

10. 23 Cal. 3 d at 319,591 P.2d at 14,152 Cal. Rptr. at 916.

11. Id. at 303, $591 \mathrm{P} .2 \mathrm{~d}$ at 3-4, $152 \mathrm{Cal}$. Rptr. at 905-06.

12. Id. at 304, 591 P.2d at 4, 152 Cal. Rptr. at 906. The court noted that these agreements were entered into under CAL. Gov'T CoDE $\$ \S 3500-3510$ (West Supp. 1978), legislation recognizing the right of local pubhic employees to bargain collectively and to enter into written memoranda of agreement regarding their negotiations. The statute does not expressly provide that the written inemoranda shall be binding. The court interpreted the statute in Glendale City Employees Ass'n v. City of Glendale, 15 Cal. 3d 328, 334-35, 540 P.2d 609, 613, 124 Cal. Rptr. 513, 517 (1975), to mean that once memoranda of understanding are ratified by the governing board of the local entity, they are binding upon the employer. From the reasoning and facts of the Glendale opmion and the language of the statute, the memoranda might be viewed as binding only with regard to the power of the employer to repudiate them. In Sonoma, Justice Mosk's opinion promulgated without discussion a broader construction: memoranda of understanding are binding contracts for purposes of determining impairment under the contract clause.

13. $23 \mathrm{Cal}$. 3d at 304, 591 P.2d at 4, 152 Cal. Rptr. at 906.

14. CaL. Gov't Code $\S 16280$ (West Supp. 1979).

15. 23 Cal. $3 \mathrm{~d}$ at 305, 59I P.2d at 5, 152 Cal. Rptr. at 907.

16. U.S. CoNST. art. I, $\S 10$, cl. 1 provides that "no State shall . . . pass any . . . Law impairing the Obligation of Contracts. ..."

17. 290 U.S. 398 (1934). 
Blaisdell contained four factors which "impelled" its finding of no impermissible impairment: 1) Minnesota had declared an emergency as justification for the law, and the severity of the "Great Depression" was an adequate basis for that declaration; 2) the purpose of the legislation was to protect a basic interest of society, not merely of particular individuals; 3) the law fit the einergency, imposimg reasonable conditions; and 4 ) the legislation was temporary, limited to the exigency which prompted it. ${ }^{18}$

In applying the Blaisdell factors, the Sonoma court particularly relied on two recent United States Supreme Court decisions. The first, Allied Structural Steel Co. v. Spannaus, ${ }^{19}$ involved a statutory modification of private corporations' contractual obligations to make employer contributions to employee pension plans. In the second, United States Trust Co. $v . \mathrm{New}$ Jersey, ${ }^{20}$ state legislation altered the rights of the bondholders of a public entity. The Sonoma court purported to apply the Blaisdell factors as they were modified and interpreted by the United States Supreine Court in these two recent cases, ${ }^{21}$ but it differed from the Court in the relative importance which it attributed to each factor.

\section{A. The Severity of the Impairment and Its Duration}

Following the Supreme Court's approach, the Sonoma court first assessed the severity of the impact of section 16280. This imitial inquiry was necessary since, as the Allied Steel court noted, "[m]inimal alteration of contractual obligations may end the inquiry at its first stage,"22 and the challenged legislation will be upheld. ${ }^{23}$ The facts of Blaisdell indicate that the duration of the impairment may also be significant since in that case the legislation that was upheld imposed only a temporary moratorium on contract obligations. ${ }^{24}$ However, where the legislation does affect vital aspects of contracts for a prolonged period, or destroys substantial contract rights, it will be struck down, ${ }^{25}$ even where

\footnotetext{
18. 23 Cal. $3 \mathrm{~d}$ at $305-06,591$ P.2d at 5-6, 152 Cal. Rptr. at 905-06.

19. 438 U.S. 234 (1978).

20. 431 U.S. 1 (1977).

21. 23 Cal. $3 d$ at $305-08,591$ P.2d at 5-7, 152 Cal. Rptr. at 907-09.

22. 438 U.S. at 245 (footnote omitted).

23. See, e.g., City of E1 Paso v. Simmons, 379 U.S. 497, 516-17 (1965): "[T] he measure taken .. . was a mild one. . . , hardly burdensome to the purchaser . . . but nonetheless an important one to the State's interest."

24. Rather than abrogate the mortgagee's foreclosure rights, the Blaisdell legislation merely extended the nortgagor's redenption period by two years. 290 U.S. at 416 . The Sonoma Court emphasized the durational element present in Blaisdell. $23 \mathrm{Cal}$. 3d at 307,591 P.2d at 6, $152 \mathrm{Cal}$. Rptr. at 908.

25. Compare Blaisdell, 290 U.S. 398 (statute upheld), with Louisville Joint Stock Land Bank v. Radford, 295 U.S. 555 (1935) (act enabling a defaulting mortgagor to retain possession of the
} 
immediate and severe conditions indicate that upholding the challenged legislation would serve a strong public purpose. ${ }^{26}$ Cahifornia cases are in accord. ${ }^{27}$

The Sonoma court relied on both the substantiality of the impaired contract rights and the duration of the impairment as factors in assessing the impact of the legislation in question. This analysis will separate these two factors, although the court did not do so.

The counties argued that the impairment was insubstantial because it affected only one contract provision (i.e., salary increases) for only one fiscal year. ${ }^{28}$ They argued that it therefore impaired contract rights no more than had the legislation in City of El Paso v. Simmons, ${ }^{29}$ where the United States Supreme Court upheld a state law restricting the reinstatement rights of defaulting purchasers of state land. The counties also relied on a decision of New York's highest court upholding emergency fiscal legislation in a case presenting similar facts. In Subway-Surface Supervisors Association v. New York City Transit Authority, ${ }^{30}$ the state legislature had responded to a fiscal crisis in the City of New York by suspending increases in salaries of public einployees. The New York court concluded that, since the employees had not yet given consideration for the wage increase, only a prospective contract right had been impaired, and that the impairment was therefore not substantial.

The Sonoma court questioned the New York court's rationale and rejected the counties' argument. It first noted that an employinent contract must be viewed as a whole: "[a]n increase in wages is frequently the very heart of an employment contract," and in this case was "inextricably interwoven" with other contract provisions in which the employees may have only acquiesced "in exchange for a wage increase." 31 Consequently, the cost-of-living increase provisions may function in

foreclosed property upon payment of reasonable rent and to redeem the property upon payment of the appraised value of the land destroys contract rights and therefore violates the contract clause).

26. See, e.g., Treigle v. Acme Homestead Ass'n, 297 U.S. 189 (1936) (depression measure limiting the right of shareholders in a building and loan association to withdraw their subscriptions invalidated); W.B. Worthen Co. v. Kavanaugh, 295 U.S. 56 (1935) (statute that greatly diminished the remedies for the security of municipal improvement bonds invalidated); W.B. Worthen Co. v. Thomas, 292 U.S. 426 (1934) (law unconditionally and permanently exempting hife insurance policy proceeds from judicial process invalidated). But see Veix v. Sixth Ward Bldg. \& Loan Ass'n, 310 U.S. 32 (1940) (Treigle statute distinguished as directed toward a private right, not the public interest).

27. See, e.g., Brown v. Ferndon, 5 Cal. 2d 226, 54 P.2d 712 (1936); Hales v. Snowden, 19 Cal. App. 2d 366, 65 P.2d 847 (2d Dist. 1937).

28. 23 Cal. 3d at 308, 591 P.2d at 7, 152 Cal. Rptr. at 909.

29. 379 U.S. 497 (1965).

30. 44 N.Y.2d 101, 375 N.E.2d 384,404 N.Y.S.2d 323 (1978).

31. 23 Cal. 3d at 308-09, 312-13, 591 P.2d at 7, 10, 152 Cal. Rptr. at 909, 912. 
multi-year memoranda of understanding as an mduceinent to employees to remain. ${ }^{32}$ On this reasoning, the court held that the wage freeze provision substantially impaired the employinent contracts.

Second, the court identified a "durational" eleinent, arguing that the impact of the legislation was not only "severe" but also "permanent" and "inninediate." 33 In Subway-Surface, the New York Court of Appeals upheld the impairment of contract benefits, noting that the rights involved had not been abrogated but merely suspended. ${ }^{34}$ The counties made a similar argument about the California wage freeze provisions, but this reasonmg failed to convince the Sonoma court. It noted that the New York statute only deferred the right to collect the wage increase for so long as the emergency period lasted. The Califorma statute, by contrast, completely eliminated the right to a wage increase. Therefore, the court held that the employees' rights to the mcrease would be "irretrievably lost" if the legislation were upheld. ${ }^{35}$ Simce the Sonoma legislation permanently altered a substantial contract right, the court concluded that the impairment was severe. Consequently, "the 'height of the hurdle the state legislature must clear' is elevated,"36 and the court, relying on the standard evolved in Allied Steel, is required to examine closely the nature and purpose of the legislation.

\section{B. An Adequate Basis for the Statute: The Presence of an Emergency}

The Sonoma court next turned to the counties' argument that an emergency may justify even a severe impairment of contract. The court conceded that, following Blaisdell, an emergeney may result from "economic" as well as "physical" causes ${ }^{37}$ and need not be of great magnitude to justify a state law impairing contract obligations. ${ }^{38}$ However, in examining the legislation before it, the court put the burden on the counties to establish that such a crisis existed.

The counties clamied that the einergency justifying the impairinent was the loss of property tax revenue due to the passage of Propo-

32. Id. at 312-13, 591 P.2d at 10, 152 Cal. Rptr. at 912. Cf. Kern v. City of Long Beach, 29 Cal. 2d 843, 856, 179 P.2d 799, 803 (1947) (pension rights of public employees serve as an inducement to them to remain in public service).

33. 23 Cal. 3d at 309, 591 P.2d at 7, 152 Cal. Rptr. at 909 (citing Allied Structural Steel Co. v. Spannaus, 438 U.S. at 250).

34. 44 N.Y.2d at 113,375 N.E.2d at 390,404 N.Y.S.2d at 330.

35. 23 Cal. 3d at 309, 591 P.2d at 7, 152 Cal. Rptr. at 909.

36. Id. (citing Allied Structural Steel Co. v. Spannaus, 438 U.S. at 245 (statute invalidated because it worked a "severe, permanent and immediate change" in contract)).

37. 23 Cal. 3d at 305-07, 591 P.2d at 5-6, 152 Cal. Rptr. at 907-08.

38. Id. at 310 n.13, 591 P.2d at 8 n.13, 152 Cal. Rptr. at 910 n.13. See also Allied Structural Steel Co. v. Spannaus, 438 U.S. at 249 n.24. 
sition 13. They pointed to the legislative statement of imtent included within the "bail-out" statute, which showed that the purpose of the limitation on wage mcreases was to perınit maintenance of essential local government services "at a higher level than would otherwise be the case," to promote full employment, and to prevent layoffs in spite of the imcome loss. ${ }^{39}$ Although recognizing the deference that courts generally pay to such legislative findings, the court stated that deference would be mappropriate where "government is attempting to modify governmental financial obligations," self-imterest is at stake."41

On its own examination of the circumstances, the Sonoma court rejected the counties', and consequently the legislature's, assertion that a crisis existed at the time the "bail-out" legislation was enacted. The court realized that local governments had lost enormous amounts of revenues because of Proposition $13{ }^{42}$ However, the court saw no evidence that local governments would not be able to pay employees for services already rendered or meet payments on outstanding obligations. ${ }^{43}$ On that basis, the court further distinguished Subway-Surface, noting that a major fiscal crisis existed in New York City when the legislation at issue in that case was enacted. ${ }^{44}$ Moreover, the union in that case had conceded this point. ${ }^{45}$ If the city had not obtained funds and drastically cut its budget, it would not have been able to pay its einployees, suppliers, and bondholders. Further, since New York City was the financial center of the state, its bankruptcy could put great strains on the state's own limited revenues. ${ }^{46}$ In Sonoma, the counties failed to show that a comparable fiscal crisis existed in Cahfornia. ${ }^{47}$

The court further suggested that, even if the passage of Proposition 13 had created a fiscal crisis, the "bail-out" legislation to which the

39. CAL. Gov'T CODE $\S 16281$ (West Supp. 1979).

40. 23 Cal. 3d at 310, 591 P.2d at 8, 152 Cal. Rptr. at 910.

41. Id. at 308, 591 P.2d at 7, 152 Cal. Rptr. at 909.

42. For example, Santa Clara County lost approximately $\$ 77,000,000$ in property tax revenues during the 1978-79 fiscal year as a result of Proposition 13. Brief for Respondent Santa Clara County at 15. The court in Sonoma estimated that local governmental entities had lost approximately $22 \%$ of their anticipated revenues as a result of Proposition 13 before grants of state "bailout" money. 23 Cal. $3 d$ at 310, 591 P.2d at 7, 152 Cal. Rptr. at 910.

43. In fact, Proposition 13 contained provisions for a higher tax rate to be imposed by local entities to service outstanding voter-approved bond issues existing at the time of passage of the initiative. CAL. Const. art. XIIIA, § I(b).

44. 23 Cal. 3d at 311-12, 591 P.2d at 9-10, 152 Cal. Rptr. at 911-12.

45. 44 N.Y.2d at 110,375 N.E.2d at 389,44 N.Y.S.2d at 328.

46. 1975 N.Y. Laws Ex. Sess., ch. 868, 1 (legislative findings). The legislature was also greatly influenced in its decision to intervene by the realization that the city would soon be foreclosed from seeking funds in the public markets. Id.

47. 23 Cal. 3d at 312, 591 P.2d at 9-10, 152 Cal. Rptr. at 911-12. 
restrictions were attached averted it. ${ }^{48}$ Therefore, the legislature was not entitled to justify the impairment by relying on the fiscal einergency that it had already eliminated with other legislation. On these grounds, the court contradicted the legislative findings and struck down section $16280.5^{49}$

\section{Critique of the Court's Analysis}

The court's initial finding that the impairment of the eunployees' contract rights was severe was logically derived from a fair assessinent of the nature of an employinent contract. However, the court's finding that no einergency existed at the time of the enactinent of the "bailout" legislation raises serious questions. First, characterization of the emergency factor as an imitial hurdle the government must overcome is unjustified by precedent. Second, the court avoided analyzing the importance of other factors such as whether the impairment is reasonably related to the circumstances for which it is the legislative response. Third, judicial contradiction of the legislative finding that an emergency existed raises the question of the relative competence of the courts and the legislature to gauge so broad a factual matter. Finally, as a result of the unclear use of precedent by the Sonoma court, a great deal of uncertainty remaims regarding the scope of the opinion.

\section{Emergency as a Threshold Requirement}

In analyzing the impairment of contract caused by the "bail-out" legislation, the Sonoma court purported to follow the criteria established in prior Umited States Supreme Court cases. An examination of precedent reveals, however, that the court did not do so. Prior cases balanced various factors, includimg the extent of the inipairinent, ${ }^{50}$ the public purpose to be served by it, the presence of any emergency proinptimg its enactment, its reasonableness, and its duration. ${ }^{51}$ In $\mathrm{Al}$ -

48. Id. at 311, 591 P.2d at 9, 152 Cal. Rptr. at 911. While the court acknowledged estimates of a $22 \%$ cut in anticipated revenues as a result of Proposition 13, it emphasized the fact that state bail-out funds had reduced the loss to only 6\%. Id. at 310-11, 591 P.2d at 7-8, 152 Cal. Rptr. at 910-11. See note 42 supra.

49. The court's conclusion that no emergency existed permitted it to avoid discussion of an argument by petitioners that the court found "appealing." $23 \mathrm{Cal} .3 \mathrm{~d}$ at 313, $591 \mathrm{P.2 \textrm {d }}$ at 10, 152 Cal. Rptr. at 912 . The argument was that since the passage of Proposition 13 by initiative was an action of the state, "any emergency which existed subsequent to its enactment was created by the state itself, and a contract may not be impaired because of a crisis created by the state's voluntary conduct." $I d$. Because it had already concluded that no emergency situation of such a magnitude as to justify an impairment of contract existed, the court did not decide the merits of this argument.

50. See, e.g., Allied Structural Steel Co. v. Spannaus, 438 U.S. at 244-45. See text accompanying notes 22-27 supra.

51. See, e.g., Allied Structural Steel Co. v. Spannaus, 438 U.S. at 242 (citing Blaisdell, 290 U.S. at 444-47). 
lied Steel and United States Trust, the Supreme Court emphasized that while the presence of an emergency was an important factor in adjudging the constitutionality of an impairment under the contract clause, it was only one of several. ${ }^{52}$ In the Sonoma court's analysis, however, the emergency factor became an initial hurdle. When the counties failed to overcome this hurdle at the outset, the court ignored the other factors.

By elevating the emergency factor to the status of a "threshold" condition for a finding of validity, ${ }^{53}$ the court increased the state's burden of proof. Prior decisions imposed no requirement that the state show a severe emergency. In City of El Paso v. Simmons, for imstance, the Court considered of paramount importance such factors as the public purpose served by the legislation, the adverse consequences to the state which might result if the legislation were imvalidated, and the necessity of leaving to the states effective means to deal with state problems. ${ }^{54}$ No emergency situation existed, nor was any required, to justify impairments resultimg from the state's action in that case. ${ }^{55}$

Moreover, an emergency could have been found under the Sonoma court's own threshold requirement. Although in Sonoma no present emergency of the magnitude of that facing New York City in Subway-Surface existed, there was a serious threat of a future fiscal crisis of that magnitude. The legislature realized that the surplus funds allotted in 1978 to local entities were limited, and that the extent of future state capacity to aid cities and counties was uncertam. In addition, the legislature was aware of the financial difficulties local entities would face in effecting spendimg reductions made necessary by revenue cuts. Local expenditures nationwide have mushroomed in recent years so that many local governments now face a "revenue-expenditure imbalance."56 In view of this local fiscal squeeze, crises similar to that confronting New York City were possible in California. It was reasonable for the legislature, in the wake of drastic revenue cuts, to conclude that an emergency did exist.

52. For instance, the analysis in Allied Steel involved a balancing of several factors. Once the Court had determined that a severe impairment was involved, it then analyzed the statute in question to ascertain whether there had been an emergency, whether an important public purpose was served by the legislation, and whether the state had evidenced a prior interest in the area governed by the statute. Only after it found that none of these factors was present did the Court strike down the statute. Id. at 250. Allied Steel did consider an assessmeut of the severity of the impairment to be the opening step of the analysis. Id. at 244-45.

53. $23 \mathrm{Cal} .3 \mathrm{~d}$ at $310,591 \mathrm{P} .2 \mathrm{~d}$ at 10, 152 Cal. Rptr. at 910.

54. 379 U.S. at 511, 513-14.

55. The Court read very broadly the Blaisdell factors, noting that "the 'economic interests of the State may justify the exercise of its contmuing and dominant protective power notwithstanding interference with contracts." 379 U.S. at 508 (quoting Blaisdell, 290 U.S. at 437).

56. Comment, State Control of Local Government Finance-A Comparative Look at the Pennsylvania System, 81 Dick. L. REv. 575, 575 (1977). 
The court's suggestion that the "bail-out" legislation alleviated any emergency that might have been caused by Proposition $13^{57}$ proves too much. The circularity of this reasoning would destroy the justification for every legislative act that passed the emergency hurdle. Following this reasoning, every statute which solved the problem at which it was aimed would remove the emergency that justified it and so invalidate itself, even if contimued application of the statute were necessary to alleviate the emergency.

\section{The Omitted Step in the Analysis: Balancing the Blaisdell Factors}

Even if the court had accepted the legislative finding that an emergency existed, an emergency alone would not justify the legislative infringement of contract rights. Under the traditional contract clause analysis, the other factors identified in Blaisdell must be balanced to achieve an equitable result im each individual case. The Sonoma court failed to reach these factors because of its inordinate emphasis on the existence of an emergency. Had it examined whether the impairment was reasonably related to the circumstances prompting passage of the legislation, it might have faulted the legislature not for erroneously finding an emergency but for imposing a cure not reasonably related to the emergency. Indeed, under the analytical directive of Allied Steel and United States Trust, the wage-freeze conditions might have been struck down as not reasonably related. ${ }^{58}$

\section{Court Competence}

The court's contradiction of the legislative finding that an emergency existed raises questions about the scope of judicial review. Ordinarily, when reviewing the justification for legislation, the court will

57. See text accompanying note 48 supra.

58. Allied Steel establishes a reasonableness test based on balancing: if the legislation is necessary to the public purpose to be served by it, and if this purpose outweighs the private interests affected, the legislation will be upheld. 438 U.S. at 247, 249-50. United States Trust had used a similarly strict standard, determining that the impairment was neither necessary nor reasonable if less onerous means were available to achieve the same end: "a State is not free to impose a drastic impairment when . . . [a] more moderate course would serve its purposes equally well." 431 U.S. at 31 . Under this standard, the "bail-out" legislation was unreasonable since the state made no showing of how the wage freeze conditions furthered the stated purpose of the legislature-maintaming essential services at the local level and preventing layoffs. CAL. Gov'T CODE $\S 16281$ (West Supp. 1979). Limiting wage increases alone, without attaching other conditions, provides no assurance that essential services will be maimtained or that layoffs will not occur. The local entities are still left free to accept the money, lay off employees, cut services, and then use the money to fulfill other, less crucial obligations. Thus, the legislation is not reasonably related to the problem it was mtended to solve, and therefore does not outweigh the private imterests in contracts impaired by the legislation. The legislature could liave guaranteed inamtenance of essential services without impairmg contract obligations by, e.g., requiring that funds received from the state be spent first on those services designated high priority by the legislature. 
accept the legislature's finding of fact. In Sonoma, however, the legislature's role as an "interested party" with respect to the contract rights its legislation infringed justified a stricter standard of judicial scrutiny. Indeed, this higher scrutiny could appear to be in keeping with the admonition of the United States Supreme Court in United States Trust that complete deference is inappropriate when "the State's self-interest is at stake." 59

However, the Sonoma court misread the mandate of that decision. In United States Trust, the Court had not refused to defer to a legislative finding of fact, i.e., that an emergency existed. Rather, it questioned the legislature's determination of the reasonableness of its response to the circumstances confronting it. ${ }^{60}$ In challenging such a determination of reasonableness, a court need only balance the various factors considered by the legislature. When the court overturns a legislative finding of fact, however, it supplants the legislature's interpretation of facts with its own. Since courts do not engage in the broad investigation and evidence gathering characteristic of legislative hearings-e.g., they are without the benefit of testimony from experts in inumicipal finance - they lack the information required to nake an accurate appraisal of economic statistics and the exigencies of municipal budgeting. ${ }^{61}$

\section{The Uncertain Scope of the Decision}

Finally, the Sonoma court, by raising the einergency factor to a threshold requirement-and thus departing from the balancing analysis used by courts with only shight modification since Blaisdell-has caused uncertainty as to the scope of the decision. Due to the court's failure to indicate inore precisely which precedent supports its analysis, it is difficult to ascertain how much the court intended to depart froin Allied Steel and United States Trust. Ostensibly, the court relied on United States Trust, particularly in its determination not to show deference to the legislative finding of an emergency in the case of a public contract. However, the analytical approach in Sonoma inore closely resembles that taken in Allied Steel, which involved private contracts. Consequently, it is unclear whether all severe impairments of contract

59. 431 U.S. at 26.

60. Id.

61. It can be argued that the United States Trust analysis called court competence into question more than that in Sonoma by asserting that a court is less competent to assess the appropriate response to a situation than to ascertain the facts which constitute it. In this case, however, the legislature's response was so clearly unrelated to the situation that it sought to cure that the court would have been on surer ground had it focused on the reasonableness of that response. See note 58 supra. 
must ineet the Sonoma einergency hurdle or only those involving public contracts.

If the basis for the decision is Allied Steel, Sonoma's threshold emergency requirement must be met in any severe impairment situation, regardless of the involvement of the state or the importance of the public purpose. Conversely, if the basis for the decision is United States Trust, then the Sonoma emergency hurdle might apply only to cases in which contracts between a private party and a public entity are involved, i.e., cases in which "government is attempting to modify governmental financial obligations." 62 In such cases, deference to the legislative finding of emergency would be inappropriate. Thus, an important question left open by the decision is whether, in order for the legislation to be upheld, a showing of an emergency inust be made only where the government is an imterested party to the contract, or whenever any contract has been more than minimally impaired.

The importance of this question is illustrated by the following hypothetical: a multi-year commercial lease between private parties provides for a yearly adjustment in rents to reflect cost of hiving increases. The legislature passes a rent control ordimance calling for a roll-back of rents to a previous year's level and for an absolute freeze on rent increases for that year. As justification for this ordinance, the legislature finds that a crisis exists in the commercial rental market.

Under a broad interpretation of Sonoma, the landlord would show that a year-long rent freeze is more than a minimal alteration of his contract rights since it affects the very heart of the contract obligationthe rent owing. Then the legislature would have the burden of showing an emergency. If it failed to do so, under Sonoma, the legislation would be struck down regardless of whether the other criteria established in Blaisdell and balanced as in Allied Steel would justify it. On the other hand, if the holding of Sonoma is limited to public contracts, then the rent control ordimance, simce it affects only private parties, would be assessed for reasonableness under the Allied Steel test. In other words, no "emergency" hurdle would be erected. This hypothetical situation ${ }^{63}$ illustrates that Sonoma has raised the contract clause to a level of new importance; it must be given greater consideration $m$ the legislative process.

A narrow interpretation of the Sonoma decision is preferable to a

62. 23 Cal. $3 d$ at 310,591 P.2d at 8, 152 Cal. Rptr. at 910.

63. This "hypothetical" situation is based upon current litigation. A residential rent control ordinance of one year's duration was struck down by the Yolo County Superior Court, shortly after Somoma was decided, as constituting an unconstitutional impairment of contract rights, under a broad interpretation of the Sonoma rule. The Court leld that no emergency existed in the City of Davis rental market. Amato v. City of Davis, No. 38966 (Yolo County Super. Ct., May 10, 1979); Anders v. City of Davis, No. 39045 (Yolo County Super. Ct., May 10, 1979). 
broad one. Raising the einergency factor to the level of a threshold requirement places a great burden on the state where public contracts are involved. This burden is justified where the state or its political subdivisions are parties to the contracts and where they will benefit froin the impairment. No such justification exists where private contracts are impaired. There the state has acted disinterestedly and greater deference should consequently be shown to the legislative assessinent of the necessity for the act. In such cases, there is even less reason to raise the presence or absence of an einergency above any of the other factors in the balancing process.

\section{III.}

The Scope of the Local Entity's Autonomy: The Home RULe ISSUE

While disposition of the impairment of contract issue was legally sufficient to decide the case, the court also discussed the hoine rule question raised by the legislative action. Yet, in holding that local entities have an exclusive power to determine the salaries of their employees, the court raised nore questions regarding the limits of home rule powers than it resolved.

\section{A. The Decision}

The hoine rule provisions of the California Constitution guarantee the right of chartered cities and counties to determine the coinpensation of their employees. ${ }^{64}$ To decide whether section 16280 violated these provisions, the court had to determine whether the power to freeze local public employees' wages was strictly that of the local entity or whether the legislature could appropriate it when local wages had become a matter of statewide concern.

The Sonoma court first chose to disregard the legislative finding that the inatter of public einployees' wage increases was of "statewide concern" and therefore subject to state legislation. ${ }^{65}$ Such a determination was not conclusive on the issue. ${ }^{66}$ The court felt that deference to the legislature was inappropriate since its finding could be overruled on two separate justifications - the state constitution's grant of authority to charter cities, and precedent upholding local control over public einployee salaries.

64. CAL. Const. art. XI, $\S \mathrm{I}$ (b) (home rule powers for charter counties); CAL. Const. art. $\mathrm{XI}, \S 5(\mathrm{~b})$ (home rule powers for charter cities).

65. 23 Cal. 3d at 316, 59I P.2d at 12, 152 Cal. Rptr. at 914 (citing CAL. Gov'T CoDE $§ 16281$ (West Supp. 1979)).

66. Id. 
The court considered the import of a 1970 amendment to article XI, section 5 of the state constitution which expressly granted to charter cities "plenary authority" to provide for the compensation of their officers and employees. ${ }^{67}$ In Ector v. City of Torrance, ${ }^{68}$ the court had relied exclusively on that amended section-which also grants charter cities plenary authority over employee qualifications-to hold that residence requirements for city employees were strictly a municipal affair. Employee compensation, like employee qualification, should be viewed as an exclusive function of charter cities under the state constitutional scheme.

Moreover, even before the constitutional provision granting "plenary authority" was enacted, California law had traditionally viewed compensation of local public employees as a "municipal affair." In other words, it is a matter over which charter cities, and to some degree charter counties, have sole power to govern. ${ }^{70}$ Prior cases have not, however, always provided clear guidelines for determining when, in a case of conflict between state and municipal laws, a matter constitutes a "municipal affair" and when it is of "statewide concern." The general approach has been to decide, on the particular facts of each case, whether, as a matter of the court's judgment, the subject is better governed by municipalities or the state. The results have been mconsistent and have provoked strong criticism from within and without the court. $^{71}$

Against this background, the Sonoma court felt justified in relying

67. Id. at 314,591 P.2d at 11,152 Cal. Rptr. at 193.

68. 10 Cal. 3d 129, 132-33, 514 P.2d 433, 434-35, 109 Cal. Rptr. 849, 850-51 (1973).

69. $23 \mathrm{Cal} .3 \mathrm{~d}$ at 317, 591 P.2d at 12, 152 Cal. Rptr. at 915. See, e.g., City of Pasadena v. Charleville, 215 Cal. 384, 389, 10 P.2d 745, 747 (1932) (overruled on other grounds in Purdy \& Fitzpatrick v. State, 71 Cal. 2d 566, 585-86, 456 P.2d 645, 658, 79 Cal. Rptr. 77, 90 (1969)); Popper v. Broderick, 123 Cal. 456, 460-62, 56 P. 53, 55 (1899); Trefts v. McDougald, 15 Cal. App. 584, 587-88, 115 P. 655, 657 (1st Dist. 1911); Burke v. Board of Trustees, 4 Cal. App. 235, 238-39, 87 P. 421, 422 (1st Dist. 1906).

70. Professional Fire Fighters, Inc. v. City of Los Angeles, 60 Cal. 2d 276, 291, 384 P.2d 158, 166-67, 32 Cal. Rptr. 830, 838-39 (1963); Ex parte Braun, 141 Cal. 204, 209, 74 P. 780,782 (1903).

71. For example, in Bishop v. City of San Josc, 1 Cal. 3d 56, 460 P.2d 137, 81 Cal. Rptr. 465 (1969), the court noted that the fact that the legislature has attempted to dcal with a particular subject on a statewide basis is not determinative of this issue. Id. at 63, $460 \mathrm{P.2d}$ at 141, 81 Cal. Rptr. at 469 (dictum). Justice Peters strongly dissented: "I must confess that I find it sonewhat incongruous that a chartered city may . . . refuse to comply with state law where the Legislature has clearly declared its intent that its statutes are to be applicable in and to the chartered city." Id. at 68, 460 P.2d at 145, 81 Cal. Rptr. at 473. Cf. In re Hubbard, 62 Cal. 2d 119, 127-28, 396 P.2d 809, 814-15, 41 Cal. Rptr. 393, 398-99 (1964) (dictum) (apparently giving the legislature the power to determine whether a matter is a municipal affair or of statewide concern). For a critique of the California court's approach to home rule analysis, see Sato, "Municipal Affairs" in California, 60 CAlif. L. Rev. 1055 (1972). In Professor Sato's view, the term "'municipal affairs' receives a hiberal constrnction when the only issue is whether the city is authorized to exercise a given power and a limited construction when the issue is whether a chartered city or the legislature prevails in the event of a conflict in the assertion of their powers." Id. at 1062. 
on a specific constitutional mandate and on prior case law governing control over municipal employee salaries. Apparently reluctant to immerse itself in the subtle intricacies of home rule analysis where it did not feel compelled to, the court chose not to even consider the counties' counterarguments. Specifically, it rejected out of hand the argument that when a conflict exists between a state law and a municipal regulation, whether the matter regulated is of statewide concern " 'must be determined frons the legislative purpose in each individual instance." "72 It further rejected the counties' second, inore substantial, argument that, as a result of the passage of Proposition 13, the threat of local fiscal crises occurring throughout the state had created a matter of statewide concern. The court did not decide this issue since the counties had failed to pass the judicial hurdle of showing a statewide emergency. ${ }^{73}$

In sum, relymg on a constitutional mandate and on precedent, the Sonoma court concluded that the determination of the wages to be paid to employees of charter cities and of charter counties was a matter of local rather than statewide concern. Thus, the state-imposed conditions on the salaries of employees of charter cities and counties unconstitutionally infringed the local government's home rule powers. ${ }^{74}$

\section{B. Critique of the Court's Analysis}

Here, as in the impairment of contract portion of the opimion, the court's sole rehance upon a facially adequate albeit superficial line of analysis to dispose of the case, coupled with its hesitancy to delve into the more complex issues presented by the situation before it, led to a tenuously reasoned decision. First, the court relied on a constitutional provision related to powers of charter cities to determine the constitutionality of a law as it apphes to charter counties. Second, the court failed to respond to the counties' argument in favor of a rule of changed circumstances, despite its potential merit. Finally, the court again required proof of an emergency before it would consider permittimg infringement of traditional home rule powers. This last point raises an important question. The court has said that local entities have sole power over their employees' wages, absent an emergency. But to erect the hurdle of an emergency in this context, where none existed in prior home rule cases, may suggest that, absent an emergency, the court will no longer permit gradual erosion of traditional home rule powers in favor of statewide interests. If so, Sonoma appears to overrule previ-

72. 23 Cal. 3d at 317, 591 P.2d at 13, 152 Cal. Rptr. at 915 (citing Professional Fire Fighters, lnc. v. City of Los Angeles, 60 Cal. 2d at 294, 384 P.2d at 169, 32 Cal. Rptr. at 841).

73. 23 Cal. 3d at 317, 591 P.2d at 13, 152 Cal. Rptr. at 915.

74. Id. at 317,591 P.2d at 12-13, 150 Cal. Rptr. at 915. 
ous decisions upholding such erosion. This critique will consider each of these questions in greater detail.

\section{Application of the Constitutional Mandate to Charter Counties}

A serious flaw in the court's reliance on article XI, section 5 is that this constitutional provision's terms apply only to charter cities. Yet, on the basis of this provision, the Sonoma court granted relief to the three petitioners that represented employees of charter counties, ${ }^{75}$ as well as to the two that represented city employees. The parallel section of the constitution providing home rule powers to charter counties contams no grant of plenary authority to provide for einployees' compensation; it does entitle charter counties to "provide for" the "compensation" of employees. ${ }^{76}$ Thus, charter counties may not have as firm a constitutional protcction against state imtervention in wage determinations as do charter cities. Almost thirty years ago, the California Supreme Court decided that county authority over its employees must give way to state policies in Bowen $v$. County of Los Angeles, ${ }^{77}$ which upheld state imposition of a loyalty oath on county employees.

Moreover, no clear line of precedent has developed providing for county hoine rule powers. ${ }^{78}$ Since these may be less than those of char-

75. The counties of Sonoma, Santa Clara, and Monterey were respondents in the suit. The sole charter city involved was the City of Long Beach. The State of California was named as a party by the California Association of Professional Employees.

76. CAL. Const. art. XI, $\S 1$ (b).

77. 39 Cal. 2d 714, 715, 249 P.2d 285, 286 (1952).

78. Bowen is one of the few California cases in which county home rule is discussed at all. The notion of county home rule is complex. The state constitution provides that a county may adopt a charter for its own government. CAL. ConsT. art. XI, $\S 3(a)$. The subsection further provides that "[c]ounty charters adopted pursuant to this section shall supersede any existing charter and all laws inconsistent therewith." Id. The constitution specifically provides that certain powers shall be included in county charters. CAL. CoNST. art. XI, § 4. Thus, the charter must provide for the compensation, terms, and removal of members of the governing body and other officers. CAL. CoNST, art. XI, $\S \S 4(b)-(f)$. This grant of authority contains a limit: county charters must provide for "the performance of functions required by statute." CAL. ConsT. art. XI, §4(d). The constitution requires that the legislature provide for county powers. CAL. ConsT. art. X1, $\$ 1$. Reading these provisions together leads to the conclusion that, at least to the extent of the powers specifically provided for in the constitution, charter counties are autonomous. This conclusion is reinforced by another constitutional provision that states:

Whenever any county has framed and adopted a charter, and the same shall have becn approved by the Legislature. . . , the general laws adopted by the Legislature in pursuance of Section 1(b) of this article, shall, as to such county, be superseded by said charter as to matters for which, under this section it is competent to make provision in such charter, and for which provision is made therein, except as herem otherwise exprcssly provided.

CaL. Const. art. XI, \& 4(g).

However, this grant of autonomy to charter counties in these sections is limited by yet another constitutional provision that states:

The provisions of Sections $1(\mathrm{~b}) \ldots, 3(\mathrm{a}), 4$, and 5 of this Article relating to matters affecting the distribution of powers between the Legislature and cities and counties, including matters affecting supersession, shall be construed as a restatement of all related 
ter cities, the court's exclusive rehance on home rule powers of charter cities was misplaced as to county governments. The court's failure to note this distinction or find other arguments for striking down the legislation as applied to charter counties and other local entities aside from charter cities $^{79}$ considerably weakens this portion of the opinion.

\section{A Rule of Changed Circumstances}

The Sonoma court did not reach the merits of the counties' contention that changed circumstances in California had transformed public

provisions of the constitution in effect immediately prior to the effective date of this amendment, and as making no substantive change.

CAL. Const. art. XI, $\S 13$. The constitutional provision in effect prior to the enactment of article $\mathrm{XI}, \S 4$ provided that the general laws "shall . . . be superseded [by county charter provisions] as to unatters for which, under this section it is competent to make provision . . . except as herein otherwise expressly provided . . . " CAL. ConsT. art. XI, § 7 1/2 (adopted 1911, repealed June 2, 1970). This section did provide, however, that charter provisions relating to powers and duties of the board of supervisors and of "all othcr county officers shall be subject to and controlled by general laws." CAL. ConsT. art. XI, \$ 7 1/2, cl. 4 (adopted 1911, repealed June 2, 1970). If under article XI, $\S 13$ the enactment of present $\S 4$ was uneant to effect no substantive change in county home rule powers, the charter counties would still be subject to the gencral laws as regards duties of county officers.

There have been relatively few cases imterpreting these constitutional provisions. In an early case, the supreme court recognized the conflict between constitutionally permitting counties to provide for duties of officers and also making them subject to the general laws in this respect. Reuter v. Board of Supervisors, 220 Cal. 314, 320-21, 30 P.2d 417, 419-20 (1934). This decision did not determine the extent to which a legislature might intervene in county affairs. The tendency of courts has been to limit the county home rule provisions to precisely those powers authorized by the constitution and then only to the extent that such provisions are not limited by it. See, e.g., Handler v. Board of Supervisors, 39 Cal. 2d 282, 246 P.2d 671 (1952); Williams v. McClellan, 119 Cal. App. 2d 138, 259 P.2d 12 (4th Dist. 1953); Hafliger v. Sacramento County, 97 Cal. App. 2d 850, 218 P.2d 993 (3d Dist. 1950); Whelan v. Bailey, 1 Cal. App. 2d 334, 36 P.2d 709 (4th Dist. 1934). Bowen, for instance, held that the State could require county employees to submit to a loyalty oath despite provisions in the constitution enabling charter counties to provide for the qualifications of their employees. "[T]liere can be no doubt that the loyalty of county einployees is not exclusively a local concern but is a matter of general statewide concern." 39 Cal. $2 \mathrm{~d}$ at 715, 249 P.2d at 286. While Pearson v. County of Los Angeles, 49 Cal. 2d 523, 319 P.2d 624 (1957), held that the charter supersedes general laws in areas where the county is constitutionally cmpowered to govern, the court made exception for "matters of statewide concern where the state has occupied the field." Id. at 535, 319 P.2d at 631-32. This confusion in the case law on the subject and the conflicting constitutional provisions render the extent of county powers ambiguous. Sonoma has not clarified this ambiguity.

79. Justice Mosk extended the holding to permit employees of general law cities and counties to obtain cost-of-living increases, whether or not already part of binding contracts. $23 \mathrm{Cal}$. $3 \mathrm{~d}$ at 319,591 P.2d at 14,152 Cal. Rptr. at 916. This extension of the holding reflects the court's desire to accord equal treatment to general law cities and counties. However, the court offered no explanation of the legal foundation for this extension. This extension to general law cities and counties has no support in the state constitution. On the contrary, the state does have authority under the constitution to provide for the governance of these entities under the general laws. CAL. ConST. art. XI, \& 7. These entities as such have no "home rule" powers. It was not reasonable for the court to assume that the state legislature would have wanted all local employees to be treatcd equally when under the state constitution the employer entities enjoy no such equal treatmcnt. 
employee compensation into a matter of statewide concern. ${ }^{80}$ It did not feel compelled to do so since the counties had failed to show the required "calamitous emergency." 81

Prior to Sonoma, it was commonly accepted that a home rule power is not immutable; it may change with circumstances. For example, in 1911, the supreme court held that a home rule city had sole power over construction of telephone facilities on city streets. ${ }^{82}$ But by 1959, it recognized that telephone service had taken on such public importance that the 1911 rule was obsolete. ${ }^{83}$ State intervention and regulation were permitted at the expense of municipal autonomy, even though no state of emergency such as that required by the court in Sonoma existed.

Moreover, in situations analogous to Sonoma, "local" concerns have become niatters of statewide interest. Courts have recognized the state legislature's increased interest in labor relations in the public sector, so that state law now governs certain phases of public employment such as workers' coinpensation and collective bargaining. Hence, in Professional Fire Fighters, Inc. v. City of Los Angeles, the court upheld state Labor Code provisions restricting the right of firefighters to jom labor organizations. ${ }^{84}$ Enactment of the Meyers-Milias-Brown Act strictly regulated procedures through which local public employers negotiate and contract with their employees. ${ }^{85}$

The legislative attempt to regulate wage increases was not unlike these recent analogous instances of legislative intrusion into the local entities' relationships with their employees. Indeed, in support of its holding, the Sonoma court could cite only cases decided before these more recent developments in the public employment sector. The court should not have dismissed the counties' arguments without consideration of these recent developnients. Even though Proposition 13 may not have created a "calamitous emergency," it did substantially change the conditions under which local governments operated in California. Local entities could no longer rely on the local property tax as a primary form of revenue, and consequently suffered tremendous revenue cutbacks. ${ }^{86}$ Ways to "stretch" these severely limited funds were of

80. See note 73 and accompanyimg text supra.

81. 23 Cal. 3d at 318, 591 P.2d at 13-14, 152 Cal. Rptr. at 915.

82. Sunset Tel. \& Tel. Co. v. City of Pasadena, 161 Cal. 265, 118 P. 796 (1911).

83. Pacific Te1. \& Tel. Co. v. City \& County of San Francisco, 51 Cal. 2d 766, 336 P.2d 514 (1959).

84. 60 Cal. $2 d$ at $294-95,384$ P.2d at 169,32 Cal. Rptr. at 841.

85. CAL. Gov'T CODE $\$ \S 3500-3510$ (West Supp. 1978). Local regulations conflicting with the requirements of the Act have been held void. E.g., Huntington Beach Police Officers' Ass'n v. City of Huntington Beach, 58 Cal. App. 3d 492, 129 Cal. Rptr. 893 (4th Dist. 1976).

86. See note 42 and accoinpanying text supra. 
overriding concern to the legislature. In such a context, preserving local autonomy im compensatimg employees would be unreasonable if it came at the expense of the greater public good of ensuring the maintenance of vital public services.

In the wake of Proposition 13, the state clearly had an interest in maintenance of services. First, if local governments had become unable to fund essential services, then the burden of maintaining them would have fallen on the state. Second, serious externahties could have resulted if the state was unable to dictate the support of certain services. For instance, inadequate sewage treatment in one community would have detrimental effects on communities downstream; inadequate fire or crime prevention in one community might endanger citizens of nearby communities. In both mstances, the threat that local governments throughout the state would fail to provide services created a statewide interest in regulating compensation of local public employees in order to preserve scarce funds needed to mamtain essential services.

\section{A Boost for Home Rule}

By failing to meet the counties' argument of changed circumstances and by raising a threshold requirement of a showing of emergency, the court reasserted the vitality of home rule principles despite growing state dommation of municipahties. But im so domg, it raised several important questions and further confused analysis in the home rule area. Even before Sonoma, the dichotomy between the concepts of "municipal affair" on the one hand and "statewide concern" on the other had led to ambiguous decisions of httle precedential value. ${ }^{87} \mathrm{Un}$ fortunately, Sonoma has inerely added to those ambiguities. Prior decisions upheld state actions in view of an important statewide interest. To now require not just a statewide interest, but also an emergency, is disconcerting. The decision nnay be viewed as a reversal of the past trend of allowing greater state mvolvement in local affairs when a statewide interest is imvolved. Whether or not Sonoma actually overruled prior decisions upholding state action on the basis of an important statewide mterest, it is clear that the state nuust now show something beyond this interest to justify imtrusion into local affairs.

87. See Bishop v. City of San Jose, 1 Cal. 3d 56, 460 P.2d 137, 81 Cal. Rptr. 465 (1969); In re Hubbard, 62 Cal. 2d 119, 396 P.2d 809, 41 Cal. Rptr. 393 (1964); Professional Fire Fighters, Inc. v. City of Los Angeles, 60 Cal. 2d 276, 384 P.2d 158, 32 Cal. Rptr. 830 (1963). For a more cogent analysis of home rule issues using the "municipal affairs"/ "statewide concern" dichotomy, see Century Plaza Hotel Co. v. City of Los Angeles, 7 Cal. App. 3d 616, 87 Cal. Rptr. 166 (2d Dist. 1970). For a discussion and critique of the mode of analysis used by the court, see generally Sato, supra note 71. 


\section{Alternative Form of Analysis: State Conditioning Power}

While Sonoma emphatically reaffirmed the vitahty of local autonomy, it did so $\mathrm{m}$ an ambiguous way because the reasoning of the case does not adequately support its broad holding. The court should have treated the statute not as a direct restraint on local control over employee salaries but as a condition placed upon a state grant to the local entities. ${ }^{88}$ The legislation in Sonoma was not an attempt to interfere with local expenditures of local funds, but an attempt to attach conditions to a grant of state funds.

In Sonoma, the court rejected the argument that the restrictions in the "bail-out" legislation should be analyzed merely as conditions attached to a grant of state monies. ${ }^{89}$ The court noted that "constitutional power cannot be used by way of condition to attam an unconstitutional result." 90 In so reasoning, the court was referring to the use of conditions that impair contract obligations. ${ }^{91}$ In this regard, the court was right. If the reliance interest of a party to a contract merits constitutional protection against direct state impairment, it also merits protection against impairment by way of indirect conditions

88. Another alternative form of analysis is possible following the framework for home rule analysis suggested by Professor Sato. See Sato, supra note 71, at 1076-78. It involves a determination of which powers ought to be allocated to local entities and which are better employed by the state. First, matters which involve substantial externalities would be subject to state control. Take, for instance, the sale and use of alcoholic beverages. If local taxes were placed on the sale of these items, a tax on hquor sold in one locality would have an impact on use and sale in neighboring localities. Second, inatters in which state policies are inade applicable to both the public and private sectors should be placed under the laws of the state. For example, the power to regulate the arbitration of labor disputes would be allocated to the state under this analysis.

On the other hand, matters relating to the "intracorporate structure" and to the means by which the city operates "effectively, responsively and responsibly should be deemed a municipal affair." Sato supra note 71, at 1077-78. Election of municipal officers is a municipal affair under this scheme. Use of this approach involves a balancing of the two interests. For instance, in determining whether regulation of cost-of-hiving increases of municipal employees should be allocated to the state, we would weigh any external impact created by the post-Proposition 13 budget cuts (substantial) coupled with a widespread state policy (evidenced by previous legislation) in uniforın public employee salaries (none) agamst the interest of the municipal government (very substantial). If the state interest outweighs that of the inunicipality, then the "bail-out" conditions should be upheld. If the municipality's mterest in its own self-deternination prevails, then the legislation should be struck down.

The advantage of this approach, when compared with that followed by the court in Sonoma, is that this analysis attempts to put soine meaning behind the concepts with which the court is dealing. It offers soine guidelines for the court to follow in atteinpting to most efficiently allocate the various governmental functions. Its major disadvantage is in its continued reliance upon the concepts of "municipal function" and "statewide mterest." Courts are generally not adept in analysis using this terminology. Moreover, it is easy in this type of analysis to begin by stating as a first premise that which in fact is to be proved.

89. 23 Cal. 3d at 318-19, 591 P.2d at 14, 152 Cal. Rptr. at 916.

90. Id. at 319,591 P.2d at 14, 152 Cal. Rptr. at 916 (quoting Western Union Tel. Co. v. Foster, 247 U.S. 105, 114 (1918)).

91. 23 Cal. 3d at 319, 591 P.2d at 14, 152 Cal. Rptr. at 916. 
attached to grants of money. But in the home rule context, different considerations are at stake. It is the local autonomy interest and not the private contract right that is constitutionally protected. A balance must be achieved between the local autonomy imterest on the one hand and the state's control over its monies on the other. Under ordinary conditions, this Note argues that it would not violate home rule principles for the state to condition grants of its monies to local entities. For, if the state has the power to give money to local entities, it should also have the power to dictate how that money will be spent. Otherwise, the state would be reluctant to inake such grants.

An analogy to the federal system is relevant. The United States Supreme Court applies a relaxed standard of review to Congressional spending power, and a strict standard of review to direct impingements on state powers under the commerce clause. For instance, in National League of Cities $v$. Usery, ${ }^{92}$ the Court found that the tenth amendment limits Congress' power under the commerce clause to regulate matters "essential to the separate and independent existence of" the states. ${ }^{93}$ On this ground, use of the commerce power as authority to extend the Fair Labor Standards Act's wage and hour provisions to state employees was deemed impermissible. ${ }^{94}$ By this attempted extension of its power, Congress had displaced the states in their essential function of structuring state employee pay scales and had impaired the states' ability to function effectively in a federal system..$^{95}$

The Court conceded, however, that Congress might be able to affect those same "integral operations of state governments" by exercising its authority under the spending power rather than under the commerce power. ${ }^{96}$ When a use of the Congressional spending power has been challenged, the Court has fallen back on a rationality standard of review: so long as there is a rational relationship between the conditions imposed and the purpose of the grant, the conditions will generally be upheld. ${ }^{97}$

Before the passage of Proposition 13, use of a rationality standard in adjudging the constitutionality of conditions attached to grants of state money and a stricter standard of review for direct intrusions into

92. 426 U.S. 833 (1976).

93. Id. at 845 .

94. Id. at 851 .

95. Id. at 848 (citing with approval Fry v. United States, 421 U.S. 542, 547 (1975)).

96. 426 U.S. at 856 n.17. Cf. Buckley v. Valeo, 424 U.S. 1 (1976) (expenditure limitations placed on candidates for federal office are unconstitutional under first amendment, but such limitations are constitutional when imposed in connection with candidates' voluntary acceptance of public financing for their election campaigns). Id. at $57 \mathrm{n} .65$.

97. See, e.g., 424 U.S. at 590-91; United States v. Butler, 297 U.S. at 85-86 (Stone, J., dissenting). 
home rule autonomy would have provided an appropriate analysis. The policies favoring protection of local autonomy are not so compelling where the state is supplying the money to meet additional requirements which it has imposed. Ordinarily, the local entity can refuse the grant of money if it does not wish to comply with the state's requirements. However, Proposition 13 dranatically reduced the ability of local entities to raise revenue; local entities which depended on property taxes as their major source of revenue are no longer free to finance their own projects and ignore offers of state aid. They need the state's money to carry out their functions. ${ }^{98}$ Hence, conditions attached to state grants, although reasonable under the relaxed federal standard of review of Congressional spending power, may contaim an intolerable element of coerciveness. We inust therefore balance the competing interests-the state's need to control its own monies versus the local entity's need to receive state funds without relinquishing control over local functions allocated to it by the state constitution.

The alternative analysis which follows first examines the local autonomy interest which has been threatened by state action to determine whether the interest is "essential" to the autonomy of the local entity. Such essential interests are limited to those functions described in the home rule provisions of the constitution. The opponents of the state action have the burden of proof. If no essential interest were involved, the rational relation standard would be applied. Where an essential local interest is threatened, the coerciveness of the state-imposed condition would be examined. The opponents of the state action again have the burden of proof. If the condition is found to be noncoercive, the rational relation standard would be applied. If coercive, the state-imposed condition would have to be related to a compelling state interest to be held vahid. The burden of proof of a coinpelling state interest would be on the proponents of the state action. If such a state interest is found, the state-imposed condition would have to be necessary to the compelling state interest to be held valid. The burden of proof at this stage would also be on the proponents of the state action. This assignment of the burden is fair because to reach this point the opponents of

98. In this regard, there is a difference between states confronted with an offer of aid from the federal government and local entities with an offer from the state government. While rejecting an offer of aid from the federal government may be a difficult decision for the state, it at least has other sources of funding available to it: it can increase income taxes, impose inheritance taxes, sales and use taxes, special taxes on liquor sales, etc. The local entity in California does not realistically have that option. Proposition 13 severely limited not only the local entity's property tax revenues but also its ability to impose new property taxes or new special taxes. See CAL. CONST. art. XIIIA. Local entities are further restricted by state law from imposing income taxes. CAL. Rev. \& TAX CODE $\S 17041.5$ (West 1970). 
the state action must have already met the high initial burden of showing an essential local interest and coercive state action.

\section{An Essential Local Autonomy Interest}

To evaluate the "bail-out" legislation according to this analysis, the court inust identify the local autonomy imterest at stake. ${ }^{99}$ In this analysis, the truly "essential" autonomy interests of the local governinent have been specifically provided for in the state constitution. Local entities, for instance, have exclusive power to provide for selection, compensation, and qualifications of their employees. ${ }^{100}$ Without these basic powers, hoine rule would be a meaningless concept. Limiting the "essential" interest to those functions specifically delineated in the constitution ensures that the state may condition grants of money in such a way as to, for instance, further its interest in uniform fair labor practices within the state. ${ }^{101}$ Such conditions will be assessed under a rationality standard. But where the state attempts to attach a condition dictating employee salary levels, even though the conditions may be rationally related to a state purpose, it will be subjected to a higher standard of review. The legitimacy of the condition will be judged by the degree of its coerciveness, the iniportance of the state interest served, and the necessity of imposing the condition to further the state interest. ${ }^{102}$

\section{The Degree of Coerciveness}

In this analysis, even if legislation threatens an essential autonomy interest, it will be allowed to stand if it is rationally related to a state purpose and is not coercive. For example, if the state had allocated grant inoney to local entities to provide for additional nonessential li-

99. At the federal level, National League of Cities found that the ability to structure state employee pay scales was an "essentiall" state interest. 426 U.S. at 845 . This categorization is too broad for purposes of this analysis since it would exclude the state from any intervention into matters affecting eunployee relations at the local level. It also increases the hikelihood that the standard will be eroded. Even in National League of Citier, the standard announced.by Justice Rehnquist does not seem clear. The Court in that case distinguished Fry v. United States, 421 U.S. 542 (1975), which had upheld inposition of the federal wage and price controls to the salaries of public employees of the states and their political subdivisions. The distinction was that in National League of Cities the legislation would increase state budgets while in Fry the act served to reduce pressures on state budgets. 426 U.S. at 853 .

100. CAL. Const. art. XI, §§ 1(b), 5.

101. Consequently, this method of analysis is consistent with the court's decision in Professional Fire Fighters v. City of Los Angeles, 60 Cal. 2d 276, 384 P.2d 158, 32 Cal. Rptr. 830 (1963).

102. It is in this regard that this inethod of analysis differs from that used by the court in Sonoma. Once the Sonoma court found that the interest violated by the legislation was protected by the constitution, it ended its analysis. In order to overcoine that barrier, the state was required to prove the existence of a severe einergency. The analysis proposed here does not create so high a threshold and considers inore factors. 
brary services and had conditioned that grant with the requirement that employees hired to provide those additional services be paid according to state salary levels or be comprised of a large proportion of women and minorities, then even though an essential autonomy interest (einployee pay scales or employee qualifications) is violated, the conditions would not be coercive. There would be a strong temptation for the local authorities to accept the money and the concomittant restrictions on their autonomy; but there is a distinction between inducement and coinpulsion, albeit one of degree. ${ }^{103}$ If the burden imposed by the conditions were too onerous for the local authorities to accept, they could simply refuse the money. They could still function as a viable entity without the proffered nonessential hbrary services. Moreover, the constitution would not hinder imposition of these conditions, since it only grants authority to entities to set employees' wages when the "compensation is paid by the city." 104 Local autonomy only extends as far as its own momies do. Noncoercive state action need only meet the rational relationship test. The hypothetical actions would both meet this test; the former is rationally related to the state purpose of helping to provide adequate coinpensation to workers within the state, the latter to providing adequate einployment opportunities to women and mimorities within the state.

But in the case of the "bail-out" legislation, the situation is different. As a practical inatter, local entities were obliged to accept the state funds or cease to perform essential municipal functions. Certainly they could have rejected the aid. But to do so would have imposed an unacceptable hardship on these conmunities. The local authorities had a responsibility to their residents to continue to provide basie services even in the face of fiscal adversity. It would have been irresponsible for them to reject the state "bail-out" funds. ${ }^{105}$ Thus, where the difference between accepting and rejecting the aid offered by the state was continued viability as a government, the conditions imposed by the state were coercive.

\section{Necessary to a Compelling State Interest}

To state that the conditions were coercive does not mean, however,

103. Justice Cardozo recognized this fact in Steward Machine Co. v. Davis, 301 U.S. 548 (1937): "[E]very rebate from a tax when conditioned upon conduct is in some measure a tempta" tion. But to hold that motive or temptation is equivalent to coercion is to plunge the law in endless difficulties." $I d$. at $589-90$.

104. CAL. Const. art. XI, $\S 5(b)(4)$.

105. As a practical matter, the state probably could not have refused to grant the "bail-oul" funds to the local entities. In view of the mood of the voting populace at the time of Proposition 13 and the existence of a large surplus of state revenues, it would have been politically impossible for the state to do otherwise than to distribute those surplus funds to the local entities. 
that the state could not have legitimately imposed them. Such conditions could still be upheld if the state could show that they were necessary to further a compelling state interest. The legislature had restricted wage increases of public employees to ensure the continued availability of funds to provide for vital services, to proinote full employment, and to prevent layoffs. ${ }^{106}$ Such a condition is rationally related to its purpose, ${ }^{107}$ but the state needed to show inore. Confronted with the threatened infringement on an essential local autonomy interest as defined in the constitution, the state had to show that the coercive condition was necessary to further a coinpelling state interest. This mterest did not have to rise to the emergency level required by the $S_{0}$ noma court. If, in the face of budget cuts after Proposition 13, there was a threatened cut in the level of essential services, then the state's compelling interest in the public health and safety of its citizens would have justified its imposition of a plan to avert the potential crisis. ${ }^{108}$

In this case, the state chose one single condition-limiting cost-ofhiving increases-to promote its goals of maintaining essential services, promoting full employment, and preventing layoffs. Limiting salary increases may indeed have served to accomphish those ends: paying each employee less ensures that more employees will be paid out of the same amount of inoney. But the test here is necessity: could other, less

106. CAL. Gov'T CODE $\S 16281$ (West Supp. 1979).

107. But for a different conclusion under a stricter standard, see note 58 and accompanying text supra.

108. In assessing the analogous relationship between the states (and their political subdivisions) and the federal government, the United States Supreme Court has shown considerable deference to state regulations designed to further public health or safety. For instance, the Court has upheld many state transportation safety regulations despite purported infringements on interstate commerce. See, e.g., Brotherhood of Locomotive Firemen v. Chicago, R.I. \& P.R.R., 393 U.S. 129 (1968) (requiring minimum crews on trains traveling farther than specified distances within a state); Bradley v. Public Utils. Comm'n, 289 U.S. 92 (1933) (upholding state's refusal to license an interstate common carrier due to traffic congestion on a particular route); Missouri Pacific Ry. v. Norwood, 283 U.S. 249 (1931) (requiring full traim crews); Morris v. Duby, 274 U.S. 135 (1927) (speed and size of trucks may be regulated); Hendrick v. Maryland, 235 U.S. 610 (1915) (state may require nonresidents traveling on highways to secure drivers' licenses); Atlantic Coast Line Ry. Co. v. Georgia, 234 U.S. 280 (1914) (requiring locomotives to be equipped witl electric headlights). Not all safety regulations have been upheld, however. E.g., Bibb v. Navajo Freight Lines, 359 U.S. 520 (1959). But the Court in $B i b b$, while striking down a state inudguard regulation, noted that "[t]his is one of those cases-few in number-where local safety ineasures that are nondiscriminatory place an unconstitutional burden on mterstate commerce." Id. at 529 (emphasis added). The Court has generally emphasized the legitimacy of the state interest in safety and the weight accorded that interest by the courts. Id. at 524. The Court has been willing, moreover, to uphold state regulation in the name of public health or safety even where constitutionally protected private interests are at stake, if a compelling state interest is shown. Thus, where states imposed criminal anarchy statutes in the face of a threatened, albeit not present, Comununist takeover of government, the Court sustained them as legitimate exercises of the states" "police powers," reasonably related to the end of securing the safety of the state, even though they imfringed upon freedoin of speech protected by the fourteenth amendment. Gitlow v. New York, 268 U.S. 652, 666-67 (1925). See also Whitney v. California, 274 U.S. 357 (1927). 
onerous, means have achieved the same end? ${ }^{109}$ The legislation contained no controls mandating those areas in which the funds allotted to the entities would be spent. These decisions were left entirely to the discretion of the governing body. Yet it would seem that guidelimes attached to the use of the grant money would have ensured maintenance of essential services and of current work force levels more effectively than the sole condition limiting cost-of-living increases. For instance, the state could have conditioned its grants to entities upon the entities' using those funds to rehire pohce officers who had received layoff notices, or for imterim garbage collection. Such measures specifically designed to alleviate the problem would have been especially appropriate in the face of the state's compelling interest, if they were of short-term duration, to be replaced as quickly as possible with a local plan for maintenance of those same services. Under the proposed analysis, such state measures, necessarily related to the important purposes sought to be achieved, would withstand close scrutiny, even if the conditions were coercive and even if an essential local autonomy interest were involved. But in the present case, the condition imposed by the state was not necessarily related to the purpose of alleviating the harm shown because means better suited to the purposes were available. Consequently, even in the face of a compelling state interest, it could not have been upheld.

\section{CONCLUSION}

Before Sonoma, decisions interpreting the California constitution showed marked deference to the legislature's determination of the need for statutes whose effect was to erode contract and home rule rights. In both the contract and home rule areas, the court in Sonoma reasserted individual and local autonoiny. Specifically, the court held that the state's nullification of wage increase provisions in memoranda of understanding between local public employees and their employers is an unconstitutional impairment of contract. Similarly, the intrusion of the state legislature into salary scales of local public employees was held to be an unconstitutional violation of home rule powers.

109. Cf. Dean Milk Co. v. City of Madison, 340 U.S. 349 (1951) (striking down municipal ordinance forbidding local sale of milk that had not been pasteurized and bottlcd at an approved plant near the city). The Court in that case noted that the local government may not erect an "economic barrier . . . [to] competition from without the state, [even] to protect the health and safety of its people, if reasonable nondiscriminatory alternatives, adequate to conserve lcgitimate local interests, are available." Id. at 354 . In that case, the city could have served the local health interests as well by sending inspectors to the out-of-state pasteurizing plants or by using available federal inspection services. Id. at 355 .

The court has used a "less restrictive alternative" analysis in various contexts. See, e.g., the application of this analysis under the contract clause in United States Trust, 431 U.S. at 31. See note 58 and accompanying text supra. 
While the result in this case as it applies to the five petitioners before the court is correct, the rationale of the decision is troubling. First the court's analysis of the impairment of contract issue is open to criticism. Its requirement of a showing of an emergency before the reasonableness of a statute impairing contracts will be tested is unjustified by precedent and too narrow a threshold requirement. Moreover, by making the emergency factor a hurdle which inust be overcome at the outset, the court ignored the importance of other factors involved in the balancing test for determining impairment of contract. The court's determination that no emergency existed in the case raises the question of judicial competence to overrule a factual finding of the legislature. Finally, the court's uncertain use of precedent raises doubt as to the scope of the decision.

Second, the court's analysis of the home rule issue raises further problems. The court relies on a constitutional provision which is open to conflicting interpretation. This reliance on a constitutional provision applicable solely to charter cities is misplaced in a decision regarding home rule powers of charter counties. Further, the court failed to respond to the argument that changed circumstances in Califorma after the passage of Proposition 13 justified state intrusion in an area which had traditionally been under local control. In this analysis, as in the impairment of contract area, the court lias raised a threshold emergency requirement whiclu is unjustified by precedent and mappropriate. Due to the raising of this thresloold emergency requirement for home rule analysis, the future impact of Sonoma is unclear. It is uncertain, after this case, what conditions-if_any-the state may impose on grants of money to the local entities.

This Note has formulated an alternative analysis which the court miglit have used to resolve the problem before it. This analysis views the state action as a use of the state's power to condition its grants rather than as a direct imtrusion into local affairs. Use of this alternative leads to the same result as that reached by the court but without raising the same problems which the Sonoma decision raised.

Carol Robertson Boman*

* B.A. 1970, Idaho State University, Pocatello; M.A. 1972, University of Nevada, Reno; J.D. 1980, Boalt Hall School of Law, University of California, Berkeley. 
Amador Valley Joint Union High School District v. State Board of Equalization. ${ }^{1}$ The California Supreme Court denied petitions challenging the validity of California Constitution article XIII $\mathrm{A},{ }^{2}$ a real property tax relief measure adopted by popular mitiative in 1978 as Proposition 13.

Plaintiffs mvoked the original jurisdiction of the California Supreme Court to resolve an issue of great public importance. ${ }^{3}$ Among the inany federal constitutional claims they advanced were charges of violation of the equal protection clause of the fourteenth amendment, impairment of the riglit to travel, violation of the contract clause, and vagueness. The court also considered a claim that the measure was void $a b$ initio for failure to meet the California "single-subject requirement" 4 for imitiatives, as well as an assertion that it amounted to a revision of the state constitution and was thus an improper subject for an mitiative.

The supreme court held that the qualitative and quantitative effects of the measure upon the state constitution were not so great or so sweeping as to constitute a "revision" insofar as they were limited to the subject of taxation, ${ }^{5}$ and hence that the measure was validly adopted by initiative as an "amendment." As to the "single subject"

1. 22 Cal. 3d 208, 583 P.2d 1281, 149 Cal. Rptr. 239 (1978) (Richardson, J.) (6-1 decision).

2. Briefly summarized, article XIII A provides for a reduction in property taxes. Section 1(a) states that ad valorem taxes on real property cannot exceed one percent of the "full cash value" of the property. In \& 1(b) the article exempts from its scope "special" assessments to pay interest on and redeem indebtcdness approved by the voters prior to the effcctive date of the article. Section 2(a) states that "full cash value" is to be the assessors' full cash value as shown on the 1975-76 tax bill in the case of property acquired before the 1975 assessment, and appraised value of the property at purchase time in the case of property acquired subsequent to the 1975 assessment. Section 2(b) provides for an inflation adjustment of up to two percent per year. Section 3 prevents the legislature from passing by a vote of less than two-thirds any measure changing the state tax structure so as to increase revenues from taxes on other than real property, and denies the legislature the power to impose new ad valorem taxes on real property or taxes on real property sales transactions. Section 4 requires a two-thirds vote of the electorate to impose special taxes other than on real property or real property transactions. Scction 5 provides for an effcctive date of July 1 following passage of the amendment, and $\S 6$ allows for severability of the provisions of the enactment should any portion of it be found constitutionally invalid.

3. Cal. Const. art. VI, § 10. See California Hous. Fin. Agency v. Elliott, 17 Cal. 3d 575, 580, 551 P.2d 1193, 1196, 131 Cal. Rptr. 361, 364 (1976); County of Sacramento v. Hickman, 66 Cal. 2d 841, 845, 428 P.2d 593, 595, 59 Cal. Rptr. 609, 611 (1967).

4. Cal. Const. art. II, $\S 8$, subd. (d); CAL. Elec. CODE $\S \S 3502-3503,3531$ (West 1970). The single-subject requirement is a safeguard against voter confusion and helps to insure that voters will not pass as part of a package a measure they would reject were it to appear on the ballot by itself.

5. The court cited McFadden v. Jordan, 32 Cal. 2d 330, 196 P.2d 787 (1948), for an illustration of what would merit characterization as a "revision" as opposed to an "amendment." The mitiative measure held improper in McFadden would have added 21,000 words to a 55,000-word state constitution, would have repealed or substantially altered 15 of the 25 articles which then comprised the constitution, and dealt with such multifarious subjects as taxes, retirement pensions, gambling, fish and game, surface mining, senate reapportionment, and oleomargarine. 
challenge, the court found that the several elements of the measure were "reasonably germane to" and "functionally related in furtherance of"6 its guiding purpose of effecting real property tax rehef and thus that there was no violation of the requirement. The court admitted that the title and summary of the initiative as originally published were ambiguous, but held that "substantial comphance" occurred when the election materials were corrected in all but two counties and the voter education pamphlet prepared by the Attorney General accurately suinmarized the measure. The court took judicial notice of the widespread public debate concerning the merits of Proposition 13 prior to its adoption as further evidence that there was little risk of voter confusion concerning its meaning. ${ }^{7}$

On reaching the federal constitutional issues, the court unanimously rejected the contentions that the ineasure violated the contract clause, was impermissibly vague, and abridged the right to travel. It held that the claim that the amendment would inevitably result in the default of various contractual obligations incurred by municipatities pursuant to prior contracts was unripe insofar as no present default was shown and a legislative fund had been established to insure against default until other sources of revenue could be found. The court also doubted that plaintiffs had standing to assert claims of impairment of contract without alleging that they were parties to a contract. Although it adinitted that some uncertainties in the coverage and application of the measure remained unresolved, the court refused to hold the measure void for vagueness since it was not penal in nature, the literature surrounding its adoption could serve as an imterpretative guide, and future legislation or regulations drawn up pursuant to the measure could be challenged on a case-by-case basis as specific probleins arose. The court held that the right to travel was not impaired by the fact that the measure dictated lower appraisals for "established" property than for "newly arrived" property, ${ }^{8}$ reasoning that the uncertainties inherent in current-value assessment would deter mobile persons from real property investment in inuch the same fashion. ${ }^{9}$

6. 22 Cal. 3d at 230, 583 P.2d at 1290,149 Cal. Rptr. at 248.

7. Id. at 231, 583 P.2d at 1291,149 Cal. Rptr. at 249.

8. Id. at 237,583 P.2d at 1295,149 Cal. Rptr. at 253 . "Established" property and "newly arrived" property refer to the status of property owners as of the end of 1975, the cutoff date specified in \$2(a) of article XIII A. See note 2 supra.

9. The court's rationale is sonewlat counterintuitive at this point. While it is true that current-value assessment exposes property owners to the risks of infiation and unanticipated appreciation of property values, these risks are spread across all property owners, later and earlier purchasers alike. Under the assessment-value approach of \& 2(a) of article XIII A, later purcliasers will bear a share of governmental expenses in proportion to the relative market values of their property - a variable subject to infiation and market appreciation-while pre-1975 purchasers will be sheltered from these forces by the fact that their properties are assessed in accordance with their 
It was only in regard to the equal protection issues that the court was not unanimous. Two equal protection challenges were urged: (1) that assessing identical properties differently on the basis of their cash value at different purchase times would deprive later purchasers of equal protection of the laws, and (2) that the two-thirds vote required to approve "special" local taxes would deny voters equal protection of the laws. The court dismissed the second of these claims briefly by noting that it could see no features which inight distinguish persons favoring the imposition of a tax as an identifiable class distinct from those in opposition. It failed to discuss the possibility that voters in households with school-aged children will be distinctly more likely to support taxes funding public education than voters whose households include no children.

Regarding plaintiffs' claim that identical homes would be arbitrarily assessed and taxed at different levels depending on the owners' date of acquisition, the court noted that states liave broad discretion in establishing classifications which they judge capable of producing a reasonable system of taxation ${ }^{10}$ and confined its scrutiny to finding a reasonable basis in public policy for the distinction drawn by the measure. The inajority found support for the acquisition-value approach in the idea that property taxes should depend on factors that are foreseeable to the average property buyer at the time of purchase rather than on the future vagaries of inflation or the marketplace. It stressed the element of voluntariness in decisions to buy property and noted that it was quite reasonable to base assessments on cost at the time of voluntary acquisition, since this would give liomeowners some control over how inuch they are assessed. Plaintiffs relied on Cumberland Coal Co. v. Board of Revision of Tax Assessments, ${ }^{11}$ a United States Supreme Court decision which held that intentional, systematic undervaluation of property situated similarly to other property assessed at full value constituted impermissible discrimination. The nuajority distimguished Cumberland Coal and its progeny as being concerned with deviations fron constitutional or statutory provisions mandating assessment on the basis of current value of property. Because article XIII A did not run afoul of any provision mandating current-value assessment but

1975 assessment figure. Thus the measure does appear to selectively discourage pre-1975 purchasers of property from selling it or engaging in like-kind exclranges.

10. See Kahn v. Shevim, 416 U.S. 351 (1974). In that case the court held that "a state tax law is not arbitrary although it 'discriminate[s] in favor of a certain class . . . if the discrimination is founded upon a reasonable distimction, or difference in state policy,' not in conflict with the Federal Constitution." Id. at 355 (citation omitted).

11. 284 U.S. 23 (1931). In Cumberland Coal the United States Supreme Court invalidated a measure which assessed at a uniform rate all unmined coal in a county despite the fact that the market value of coal mined in different parts of the county differed substantially. 
represented a novel approach to property taxation based on acquisition-value assessinent, it was not governed by the holding in Cumberland Coal.

In her dissent, Chief Justice Bird argued that the measure violated the right of property owners to equal protection of the laws insofar as the differential treatinent of pre-1975 and post-1975 purchasers ${ }^{12}$ created a favored class without any policy-related reason for doing so more specific than administrative convenience. She found the tax scheme in Cumberland Coal functionally similar to that under article XIII $A$ in that in neither case would assessed values reflect actual market values. The Chief Justice pointed to the plight of military familics required to change their residence periodically and of disaster victims who are forced to move as evidence of a lack of foundation in reasonable policy, since article XIII A would result in these persons having to pay higher taxes in inflationary times than they would under a currentvalue system. She also pointed out that homeowners whose property decreases in value are forced to bear a constant assessinent under article XIII A, and further noted that any assuinption that later purchasers are somehow better able to bear heavier tax burdens is unfounded in view of the rising inflation rate and increases in the mortgage payments that new homeowners inust pay. The inajority opimion assumed these flaws to be subject to legislative and regulatory correction.

The court accepted the Amador Valley case as raising issues of "great public importance," 13 apparently seeing the need for proinpt resolution of the issues as great enough to overcoine the fact that there was no present controversy as to many of the points raised. It stressed the limited nature of its inquiry at the outset, noting that it did not intend to pass judgment on the social wisdom or general propriety of article XIII A except insofar as was necessary to analyze it constitutionally. The situation facing the court was somewhat unique in that it was confronting a measure passed by the direct vote of the citizenry rather than one passed by a legislature or an administrative body, and a greater degree of deference than usual imght have been the expected response. Nevertheless, the majority opimion is uncomfortably deferential in several respects, particularly with regard to the equal protection claims. Even assuming that a rational basis standard is the proper one to use in reviewing a tax assessment law or schenie on equal protection grounds, ${ }^{14}$ the majority failed to analyze the rationality of article XIII

12. See notes 2 and 8 supra.

13. 22 Cal. 3d at 219, 583 P.2d at 1283, 149 Cal. Rptr. at 241; see note 3 supra.

14. It is at least arguable that a more stringent standard of review is called for in cases such as Amador Valley where a measure adopted by popular initiative is attacked as the act of a majority seeking to impose its will upon a minority, since one function of courts is to check acts of 
A as fully as one feels it should have. At first glance, a system that bases property taxes only on factors that are foreseeable at the time of purchase is very appealing, especially im view of the fact that many homeowners view their home as a place to live rather than as an investment and cannot be deemed to have placed primary emphasis on the projected activities of the real estate market when they made their decision to purchase their home. One's sympathies are evoked by the specter of a property appreciating in value to the point where taxes based on current value force the homeowner to sell. On closer inspection, however, one becomes aware that there is seldom much that is truly "voluntary" about when and in what fashion people become homeowners. The young, the poor, and the involuntarily mobile would doubtless be surprised to learn that their failure to acquire a home im or before 1975 was the result of voluntary choice, and there is no a priori reason to beheve that those who had the luxury of being able to make that choice were in the majority of Cahfornia society. At the very least, the court's discussion of the reasonableness of an assessment system predicated largely on the assumption that people are free to choose when to become homeowners should have probed this assumption in some depth. There is no indication from the text of the opmion that the majority even considered it.

The majority's treatment of the Cumberland Coal case is also unsatisfying $\mathrm{m}$ that it seems to pay attention only to the different circumstances under which that case arose and to ignore the theory underlymg the opinion. The majority should have exammed whether, as the Amador Valley plaintiffs alleged, the theory underlying the Cumberland Coal decision and its progeny was that identical properties with the same current market value should be taxed equally. Such a theory would presumably cover a statutory system of tax laws just as it would a single tax law at variance with a statutory system, and would thus remove the basis for the distmction made by the majority.

In the final analysis, however, perhaps the most troublesome aspect of the Amador Valley opinion is the fact that the court allowed the plaimtiffs to argue the case at all. The majority opinion expressed doubts as to the ripeness of the case at several points, but was strangely untroubled by the lack of a concrete controversy except with regard to the claini that article XIII $\mathrm{A}$ impaired existimg contracts. ${ }^{15}$ Its eager-

oppression and an initiative is an even more direct expression of majority will than a legislative action or an aduninistrative order.

15. The contract-clause claim was the only one advanced which the court refused to adjudicate on the merits, even though plaintiffs failed to allege any facts which would have made out a claim of specific harm. As to the equal protection issues, the court noted this and mentioned the possibility of decliming to "consider the issue in the abstract" and waiting for the advent of an "actual controversy wherem the [question] is pivotal," but decided instead to "treat the equal 
ness to hear the case on account of its apparent public importance seems to have triumphed over its judgment in granting standing to a group of plaintiffs who had no specific stake in any of the arguinents they were making. This lack of personal stake may account at least in part for the incompleteness of the majority's reasoning regarding the substantive equal protection claims. ${ }^{16}$ While the Amador Valley case will be fondly remembered by the majority of California's voting population for having put the constitutional seal of approval on Proposition 13 , it will no doubt be viewed more bitterly by would-be plaintiffs in the future who may have pressing personal reasons for wanting to litigate some of the issues decided in Amador Valley, but who will be precluded from doing so by the precedential effect of the decision.

protection issue as constituting an attack upon the face of the article itself' and reach the merits, 22 Cal. 3d at 233, 583 P.2d at 1292, 149 Cal. Rptr. at 250.

16. The personal-stake requirement functions to insure quality of the judicial process by preventimg future courts and future litigants in a better position to decide or argue an issue from being bound by a judgment that is "inferior" by virtue of its not having been argued as strongly as it could have been. The assumption courts make is that vigorous, focused, and thorough advocacy is more likely to occur when the litigants have specific rights that depend visibly on their ability to convince the court that their position on the issue at bar is correct than when they do not, and that the court's decisionmaking inust be "informed" by the litigants' advocacy. See, e.g., Schlesinger v. Reservists Comm. to Stop the War, 418 U.S. 208, 221 (1974); Flast v. Cohen, 392 U.S. 83, 96-97 (1968); Baker v. Carr, 369 U.S. 186, 204 (1962); United States v. Fruehauf, 365 U.S. 146, 157 (1961). See generally Brilmayer, The Jurisprudence of Article III: Perspectives on the "Case or Controversy" Requirement, 93 HARv. L. REv. 297 (1979). 